\title{
REAL ESTATE BROKERS: CONTINUING COMMISSIONS AND THE LANDLORD-TENANT RELATIONSHIP
}

A REAL estate broker, when he brings two parties together as landlord and tenant, catalyzes an economically valuable relationship. In renting small, residential properties, the broker characteristically is little more than the landlord's agent. ${ }^{1} \mathrm{He}$ lists the offered property and attempts to procure any tenant who will accept the landlord's terms. ${ }^{2}$ The average tenant does his own scouting. ${ }^{a}$ But increased use of the long-term lease to develop valuable urban realty ${ }^{4}$ has made private land planners of many brokers who specialize in creating such leaseholds. Shrewd rental of business property demands expertise.

1. The terms "broker" and "agent" are often used interchangeably. Dangcl, Real Estate Brokers, 7 L. Soc. J. Supp. (1937). That usage is not wholly accurate. A person who generally engages in selling, purchasing, financing, or leasing real estate for others is a "broker." Strictly speaking, he is an "agent" only of a particular client-and only when the principal has authorized the agency. WALKER, REAL EsTATE AGENCY § 3a (2d ed. 1922). See also MacChesney, The Law of Real Estate Brokerage \$ 7 (1938).

2. The "listing" creates a unilateral contract under which the landlord agrees to pay a commission if the broker procures a tenant and/or performs other services stipulated. Mechem, OUtuine of the LAw of Agency $\$ 560$ (4th ed. 1952). For a recent treatment of problems involved in the listing of realty, see Wallace, Promisory Liability Under Real Estate Brokerage Contracts, 37 Iowa L. REv. 350 (1952). Rarely is the listing contract a bilateral one under which the broker promises to use his "best efforts" to secure a tenant. But such contracts may be made. PFeIFFer, NEw YoRK LAW OF RENL Estate Brokerage 37 (1929); Walker, op. cit. sipra note 1, Form \#3 (both dealing with attempts to find purchasers). Usually the broker's only activities in connection with the listing are to advertise the property and to show potential tenants the premises. Brokers who list property for rent, however, may also serve as managing agents. In that capacity they are generally authorized to collect rents, lease premises, pay bills, and decide on repairs. See page 685 infra.

3. Despite continuing shortages of residential property for rent, "tenant's brokers" are rare. A random sampling of classified advertisements in The New York Times indicates that brokers advertise extensively properties they have listed for landlords, but they do not advertise tenants' wants.

4. See Comment, 48 YalE L. J. 1400 (1939).

Property owners may prefer long-term leases to outright sales for a variety of reasons. Much valuable urban realty is held by institutional investors and others who can afford to retain ownership for an indefinite period. By leasing, they reap the speculative rewards of the continuing trend towards urbanization without bearing the hardship of developing the land. Ownership of the fee in realty leased for a long term may provide a secure investment. And the lease device may offer tax advantages. See NiEnuss \& Fisher, Problens of Long Term Leases 1-3 (Michigan Business Studies \#8, 1930).

Potential property users, in turn, may prefer to rent rather than buy. By doing so they may minimize the initial outlay required. And as a means for financing the occupancy of costly property, continuing rental payments may be more attractive than available mortgage terms. Ibid.

5. Norta, Real Estate Selling and Leasing 131 (1938). Real estate brokers who merely sell or lease small residential property are also planners to some extent; they must fit people to property. See Senrenow, Survey of Real Estate Brokers license LAws 13-16 (1941). But the complex variables which brokers dealing in business prop- 
Hence a landowner often hires a broker to find the tenant who can utilize the land most efficiently. ${ }^{6}$ Or a would-be tenant may employ a broker to find the most advantageous location for his enterprise. ${ }^{7}$ In either case, the broker is called upon to assume a large part of the responsibility for creating a satisfactory relationship. ${ }^{8}$ In order to make a wise decision, he may undertake surveys of available resources, analyze neighboring land uses, and even collect parcels for his principal. The broker's skill in performing his function often determines the economic value of the leased realty.

Courts generally feel that the broker should be compensated for the effort i he expends. Standard doctrine holds him entitled to remuneration as soon as he has found a party "ready, willing, and able" to rent..10 When the party engaging the broker then refuses to enter into a lease, courts grant the broker an action to recover commissions. ${ }^{11}$ Only a contract denying the broker such a right will evoke a different judicial response. ${ }^{12}$

erties must take into account make their efforts more like those of planners. See Fismes, Princtples of Real Estate Practice 41 (1925). See also note 9 infro.

6. See, e.g., Williams \& Co. v. Groverville Corp., 256 App. Div. 683, 11 N.Y.S.2d 413 (1st Dep't 1939). From the landlord's point of view, this means finding the use that will result in the greatest rental. See note 9 infra.

7. See, e.g., Doll v. Albert Weiblen Miarble \& Granite Co., 207 La. 769, 22 So.2d 59 (1945).

Often the plan to lease a particular location will emanate from the brolser. See, c.g., Haber v. Bond Stores, 178 F.2d 836 (6th Cir. 1949); Benson \& Nortr, Real Estate Princtples and Practices 140 (1925); McMichaer, Leases Perceitiag, Shoms arid LONG TERar 246-S (4th ed. 1947). For an account of the planning of a recent large transaction by a broker and a description of the complexities that may be involved in completing a real estate deal, see Kahn, Profile-Openings and Closings $I I$, The New Yorker, Feb. 20, 1954, pp. 44, 55-61.

Generally a broker cannot act as agent for both landlord and tenant at the same time. Cf. note 1 supra. By attempting to do so he forfeits commission recoveries, unless both principals have assented to his dual agency. MfECHEx, op. cit. stpra note $2, \$ \S 502-03$.

8. NORTH, op. cit. supra note 5, at 1-3, 131-3.

9. Brokers who seek desirable tenants must weigh a variety of potential business uses. See Babcock, Valuation of Real Estate 56-9 (1932); Kriskert, Rent Estaje Appraisai and Valuation c. 14 (1933).

Techniques for evaluating locations are quite advanced. See, c.g., discussion of the Wezlich studies of pedestrian traffic in MCMIrchaEL, op. cit. supra note 7, at 92-9. See also RATCIIFF, URBan LAND Ecovosucs c. 13 (1949). And the tenant's need to be near his markets or sources of supply are carefully evaluated. See Nonrn, op. cit. sibpra note 5 , at 368 .

10. E.g., Cohen v. Ames, 205 Mass. 186, 91 N.E. 212 (1910). See NeLso:t, LAw of ReAL Estate Brokerage $\$ \$ 93,103$ (1928); Pfeifrer, op. cit. supra note 2, $\$ \S 59-62$; Schwhrtz, Brokerage and Extploystent Contracts 125 (1942); Walrer, op. cit. stspra note $1, \S 204$. A number of problems concerning the meaning of "ready, willing, and able" have produced a prodigious amount of litigation.

11. Merwin v. Shaffner, 31 Cal. App. 374, 160 Pac. 684 (1916) ; Milten v. Rapsport, 339 Ill. App. 509, 90 N.E.2d 297 (1950); Magann v. Lawlor Bros. Theatre Co, 312 MIass. 317, 44 N.E.2d 774 (1942) ; Tanenbaum v. Remford Corp., 185 Misc. 012, 57 N.Y.S.2d 415 (Sup. Ct. 1945). See also SczWartz, op. cit. supra note 10, at 197-8.

12. Many brokerage contracts delay payment of commissions by maling them conditional upon the tenant's payment of rent. See page sux infro. 
When the broker's efforts have produced a consummated lease, he has an unquestioned right to a commission $;^{13}$ but the amount to which he is entitled may remain in issue. Execution of a brokerage contract setting compensation frequently precedes the closing of a lease. ${ }^{14}$ In contracting, the broker and the leasing parties typically intend to make the broker's pay reflect the success of the lease relationship-its economic value to the parties. ${ }^{15}$ This value is generally taken to be the total rental under the lease; the broker's commission is usually a percentage thereof. ${ }^{10}$ Thus his fee increases as the dimensions of the leasing transaction expand and his skill becomes more crucial. Even where the tenant has hired the broker to find a landlord, higher rental usually breeds a brokerage contract calling for a higher commission. ${ }^{17}$ Where no express brokerage contract has been made, the "ready, willing, and able" doctrine

In the absence of agreement to the contrary, of course, the broker's action for commissions runs against the party that hired him. E.g., Doll v. Albert Weiblen Marble \& Granite Co., 17 So.2d 313, 315 (La. Ct. App. 1944), rew'd, 207 La. 769, 22 So.2d 59 (1945) ; MECHEM, op. cit. supra note $2, \S 560$. Customarily, however, the landlord agrees to pay for the broker's services, even where the tenant originally hired the broker. Sec, e.g., Doll v. Albert Weiblen Marble \& Granite Co., supra at 314. Where the tenant is a responsible business firm, such as a chain store organization, or where a long term lease vests much of the control over the property in the tenant, the broker may contract to receive his commissions from the tenant. Interviews with brokers in New Haven, Con1necticut and New York City during the Spring of 1953 (hereinafter cited as INTERviews).

13. To recover commissions, a broker must show that his efforts were the "procuring cause" of the creation of the lease relationship. Weinberg v. Smith, 152 N.Y. Supp. 1030 (Sup. Ct. 1915) ; Brumfield v. Pottier \& Stymus Mfg. Co., 1 Misc. 92, 20 N.Y. Supp. 615 (City Ct. 1892) ; De Bolt v. Pointer, 204 Okla. 167, 228 P.2d 182 (1951). The same rule prevails where the broker seeks to recover commissions on sales. See, c.f., Semenow, Pennslyvania law of Real Estate Brokerage, Landlord and Tenant 43 (1931) ; WALKER, op. cit. supra note $1, \S 446$.

14. INTERviEwS. More often than not, the broker's contract is made when the property is first listed. See note 2 supra. But the contract may be modified or made more specific at the time of closing. INTERviews.

15. BENSON \& NoRTH, op. cit. supra note 7, at 139 . This conforms to practice in regard to compensation for many other services, such as attorney's fees. Sce Woov, FEE CONTRACTS OF LAWYERS 84-91 (1936).

16. WALKER, op. cit. supra note $1, \S 196$. See also the Real Estate Board Commission Rules collected in MCMirchael, op. cit. supra note 7, at 547-54.

Since leases vary greatly in dividing between landlord and tenant the host of obligations connected with the ownership of land, the term "total rental" glosses over a multitude of problems. No attempt will be made here to catalogue non-cash items which may be considered rent. Real Estate Board rules in a few cities deal with some of these problems. See, e.g., rules for Indianapolis, Indiana and Salt Lake City, Utah, cited in MCMich AEL, op. cit. supra note 7, at 549, 552. See also note 89 infra and accompanying text. In many instances, the cash payments from the tenant to the landlord are the basis on which the broker's commission is computed. But in other cases, non-cash items must be considered. See page 679 infra.

17. See, e.g., Doll v. Albert Weiblen Marble \& Granite Co., 207 La. 769, 22 So.2d 59 (1945) ; E. O. Bailey \& Co. v. Union Planters Title Guaranty Co., 33 Tenn. App. 439, 232 S.W.2d 309 (1949). 
again assures the broker of reasonable compensation. ${ }^{18}$ Local custom, as formulated in Real Estate Board rules, ${ }^{10}$ decrees what amount is reasonable. ${ }^{20}$ By relying on Board rules, courts fix remuneration at a percentage of total rent, ${ }^{21}$ thereby simulating the intent normally underlying express contracts. .

Computing the broker's commission at the inception of the lease may lead to inaccuracy. If figured then, compensation is geared to the expectel value of the relationship; the broker receives a percentage of the total rents called for by the lease. ${ }^{22}$ But subsequent events may alter the actual value of the

18. Where no express contract was proven, some courts have spolen of broliers' claims as suits on the common counts. Lyne v. Warriner, 44 So.2d 811 (Fls. 1950); MIullen \& Woods, Inc. v. 615 W. 57th St, 144 Mfisc. 697, 259 N.Y. Supp. 250 (Mfunic. Ct. 1932), rei'd, 146 Mísc. 599, 262 N.Y. Supp. 467 (Sup. Ct. 1933). See Scrwarrz, op. cit. supra note 10 , at 238 . Regardless of terminology, the broker must prove at least an implied contract of agency before he can recover. See 6 Ixtrasumal (N.Y.U.) L. Rev. 249 (1951.). Even where the broker's contract is express, the commission rate is often not stated. Courts must fill in the ambiguity. Sexexow, Pensisumuma Law of Real Estate Brokerage, Landord and Tenaxt 15-1S (1931).

By enacting statutes of frauds, some states have barred actions by brokers to recover on oral brokerage contracts. For a compilation of relevant statutes, see 2 Cosnix, Co:iTRACTS $437 \mathrm{n} .92$ (1950). But such statutes generally have been held to apply only to actions for commissions on sales, and not to commissions on leases. Klie v. Hollstein, 98 N.J.L. 473, 120 Atl. 16 (1923) ; cf. Jaffe v. New York Towers, 108 N.I.S.2d 193 (City Ct. 1951). And additional commissions sought by the broker when the tenant purchases the premises are outside the statute. Burt v. Brownstone Realty Co., 95 X.J.L. 457, 112 Atl. 883 (1921) ; 2 CoRBIn, Contracts 43S (1950). For discussion of other problems connected with oral agreements, see note 74 infra.

19. Real Estate Boards are private associations of local real estate men, often including owners and mortgage holders as well as brokers. Fisher, Prunciples or Real Estate Practice 254 (1925). Many local boards are affiliated with the National Association of Real Estate Boards. The local boards promulgate suggested-often minimumbrokerage fees. See United States v. National Association of Real Estate Boards, 339 U.S. $485,488,494$ (1950).

20. E.g., Johnson v. Miclean, 19 So.2d 581 (La. Ct. App. 1944); Grether v. DiFranco, 178 S.W.2d 469 (Mo. App. 1944). In the Grether case the court held that, since the local Real Estate Board's rate had not been shown to be unreasonable, the amount fixed by the Board was the only amount which a jury could reasonably find as damages. See also Thomas v. Piedmont Realty \& Development Co., 195 N.C. 591, 143 S.E. 144 (1928).

Parties may specifically contract to be bound by Board rules. E.g., Jack E. Cloyd Co. v. Taber, 102 Cal. App. 384, 282 Pac 979 (1929); Mitchnik v. Brennan, 159 Misc. 287, 286 N.Y. Supp. 609 (Munic. Ct. 1936).

21. Real Estate Board rules almost invariably set commissions for leasing at a fercentage of rental. The percentages often vary with the size of the total rent. In New York City, for example, the suggested percentage rate for leases involving more than $\$ 1,000,000$ in rentals is lower than that for smaller leases. And the percentage rate generally is smaller for a long term lease than it is for a short one. See MfcMlrcines, op. cit. supra note 7 , at 547-54.

22. In this situation the broker receives a percentage of all the rental which the tenant unconditionally obligates himself to pay. Jack E. Cloyd Co. v. Taber, 102 Cal. App. 384, 282 Pac. 979 (1929). He does not initially receive a percentage of rent attribu- 
relationship. That value will increase if the leasing parties later agree to increase rental rates. ${ }^{23}$ Conversely, the actual value may decline; the tenant may fail to pay rent. In any such event, the broker has received a sum not representing a standard percentage of the benefit which the parties derive from the lease.

Nevertheless, the broker may be paid when the lease is closed. He has an enforceable right to a commission at that time, ${ }^{24}$ unless the brokerage contract expressly provides otherwise. ${ }^{25}$ And in many instances, the parties do not care to write a contract delaying payment of the broker. ${ }^{20}$ When a small, short-term lease is involved, making multiple payments is impractical. The chances of substantially overpaying the broker are minimal. And the broker may be content to settle for immediate and certain payment, even though by waiting he might receive more. In the small lease situation, therefore, the broker is normally paid in full ${ }^{27}$ when the lease is signed. ${ }^{28}$ When he becomes thus obligated to a broker, the landlord often requires the tenant immediately to make an extra payment sufficient to cover his expenses, ${ }^{20}$ including the brokerage commission. Termed "security rental," this amount is considered a pre-payment of rent for a period ending the lease term. ${ }^{30}$ This practice is designed not only to insure the landlord against an out-of-pocket loss upon the tenant's later nonperformance, but also to deter the tenant from defaulting. Incidentally it assures the broker of his commission.

\section{DefERRED COMPENSATION CONTRACTS}

Parties to a large, long-term lease, however, may not pay the broker his full commission upon creation of the lease. To do so might be financially impossible or imprudent. And where the lease calls for rentals computed by means of a flexible formula, prospective measurement of even the potential value of the relationship may be impossible.

table to a period for which the tenant is given an option to renew. See text at notes 50,51 infra. But the broker may recover for the renewal period at some later date. See page 673 infra.

23. See page 677 infra.

24. The right to commissions may arise even earlier. Courts generally hold the broker entitled to compensation as soon as he finds a party "ready, willing, and able." See text at note 10 supra. Certainly the broker's action is mature by the time the lease is closed.

25. Many brokerage contracts make the duty to pay the broker conditional upon the tenant's paying rent. See page 669 infra.

26. INTERVIEWS.

27. But see note 22 supra.

28. INTERVIEWS.

29. McMrchaEL, op. cit. supra note 7, at $\mathbf{1 5 .}$

Of course, a pre-payment will not serve the purpose of covering broker's commission expenses when the tenant is to pay the broker. But customarily the landlord assumes the obligation. See note 12 supra.

30. McMichaEL, op. cit. supra note 7, at 15-16. 


\section{"If, As, and When" Agreements}

The very size of the brokerage commission may preclude immediate payment in full. The broker's fee for creating a long-term lease may be imposing. ${ }^{31}$ And frequently the leasing parties need their money for other business purposes, such as the erection of a building on the leased premises. ${ }^{32}$ In that event, the broker may forego a lump-sum payment, and contract instead to accept installments payable during the lease term. ${ }^{33}$ Where present lack of funds is the contracting parties' only concern, the size of each installment is computed when the lease is closed. ${ }^{34}$

The parties may, however, be concerned not only about the size of the broker's commission, but also about predicting the success of a long-term leasehold. Such a lease's actual value may turn out to be substantially less than its potential value appeared to be. ${ }^{35}$ If so, pre-payment to the broker will have constituted a significant over-payment. And because the value of the long-term lease depends so heavily on the broker's skill in setting it up, the leasing parties may want the broker to share the risk of success. Under these circumstances, the broker signs a contract which entitles him to a percentage of each rental payment only "if, as, and when" it is actually made. ${ }^{36}$

As written, an "if, as, and when" contract is intended to mirror precisely" the actual value of the lease relationship; the tenant's failure to pay rent for any reason will cut off the broker's commission. In a similar context, however, decisions have tampered with the contractual intent. Where a party who engaged a broker to arrange the sale of realty later frustrates the sale,

31. If a lease calls for $\$ 100,000$ a year rental for 20 years, the current standard brokerage commission in New York City would amount to $\$ 20,250$. RenL Estate Bonro of New York, Comaission Rates and Rules (1952).

32. See NorTH, op. cit. supra note 5, at 516 .

33. E.g., Jack E. Cloyd Co. v. Taber, 102 Cal. App. 384, 282 Pac. 979 (1929).

34. InTERvinws. Landlords may be short of funds with which to pay the brolser immediately and may agree to pay him on a fixed future date. See, e.g., Hirshaut v. Ace Hotel Corp., 270 App. Dlv. 314, 59 N.Y.S.2d 758 (3d Dep't 1946) (payment of original commissions delayed until hotel season).

35. See pages 667-8 supra. Parties often contract for long periods in order to assure recoupment of money expended to improve and adapt the land for the tenant's use. See Comment, 48 Y ALE L.J. 1400, 1405-S (1939). But subsequent changes in neighboring uses, available resources, or general changes in the economy, may malie continuation of the lease unprofitable, or less profitable than other uses.

36. E.g., Davis v. Nichols, 124 S.W.2d 881 (Tex. Civ. App. 1939). The term "if, as, and when" is only one of many employed in agreements making the broker's commission contingent upon additional events subsequent to his procuring a party "ready, willing, and able" to enter into a lease. Terms which have been construed to create such a condition include: "[commissions payable] out of [rental] money received," Lind v. Huene, 205 Cal. 569, $271 \mathrm{Pac}$ 1087 (1928); "if and when," Colleton v. Malmstrom, 8 N.J. Mise. 418,150 Atl. 230 (Sup. Ct. 1930). Where the parties contract out of the "ready, willing, and able" doctrine in the sales situation, an even greater variety of terms is used. See Note, Special Conditions in Real Estate Broherage Contracts, 32 CoL. L. Rev. 1194 (1932). 
several courts have ignored "if, as, and when" language. They have allowed the broker to recover for the reasonable value of his services. ${ }^{37}$ The terms of the brokerage contract are said not to bar the broker's action, because the frustrating party is estopped from relying on a contract under which his own non-performance causes the broker to lose his fee. ${ }^{38}$ Courts might be tempted to transport this doctrine into the situation where the broker's client has caused interruption of a lease relationship. But such an extension would be ill-advised. "If, as, and when" agreements represent leasing parties' attempts to escape having to pay sizeable brokerage fees even after the lease relationship has deteriorated. It seems sound to enforce the parties' agreement that when the relationship created by the broker falters, the broker's commission shall also suffer. Had the sales cases barred the broker's claim, the broker would have been denied any compensation for his efforts; fairness thus demanded a recovery. ${ }^{39}$ But in the lease context, enforcing an "if, as, and when" agreement as written will seldom mean that the broker gets nothing. ${ }^{40}$ The broker's commission will merely be reduced as the success of the relationship wanes.

\section{Contracts Based on Variable Rental Leases}

Apart from their desire to share the risk of the lease's success with the broker, leasing parties may postpone payment of the broker's commission because even the expected value of the leasehold cannot be computed at its inception. In order to apportion the business risk between landlord and tenant, many modern commercial leases provide for periodic readjustment of rental to make it conform to economic fluctuations. ${ }^{41}$ Others measure each year's

37. See 43 Col. L. Rev. 108 (1943); Note, 32 Col. L. Rev. 1194, 1200 (1932); SCHWARTZ, op. cit. supra note 10, at 189 .

38. Stern v. Gepo Realty Corp., 264 App. Div. 265, 35 N.Y.S.2d 240 (1st Dep't 1942), aff'd, 289 N.Y. 274, 45 N.E.2d 440 (1942); Morgan v. Calvert, 126 App. Div. 327, 110 N.Y. Supp. 855 (2d Dep't 1908) ; cf. MECHEM, op. cit. supra note 2, § 567. Some cases reach the same result not on an estoppel rationale, but on the ground that the broker received no consideration when he agreed to forego his right to commissions upon finding a party "ready, willing, and able." The "if, as, and when" provision is therefore decmed unenforceable. $C f$. Abegglen v. Burnham, 91 F. Supp. 61 (D. Idaho 1950), aff'd, 187 F.2d 1021 (9th Cir. 1951).

39. See, e.g., Sandefur v. Hines, 69 Kan. 168, 76 Pac. 444 (1904); Neff v. Schrader, 49 N.D. 213,191 N.W. 466 (1922).

40. It would be an unusual case in which the lease relationship had been so poorly constructed that it collapses before substantial rents-and substantial brokerage commissions-have been paid. The pains which brokers take in creating business leases seem fair assurance that most leases will meet with some success, initially at least. See text at notes 4-9 supra. And where the lease relationship is abruptly halted by events beyond the control of the broker or the leasing parties, the broker should share the risk of loss.

41. Some leases provide for predetermined "step-ups" or "step-downs" in rent at specific dates. These leases are not variable rental leases. The broker's commission need not be withheld, because total rental contracted for by the parties may be computed at the inception of the lease. True variable leases include "re-appraisal leases," which require a recomputation of rents periodically to account for economic changes not anticipated by the original rental rates. See NIEHUSS \& FISHER, op. cit. silpra note 4, at 10-20. 
rental as a percentage of the tenant's sales. ${ }^{42}$ Since the broker's commission is normally computed as a percentage of rental, compensation must be delayed at least until the amount of rent payable can be ascertained. ${ }^{43}$

When rent is determined by the tenant's sales, some courts permit the landlord to sue the tenant for damages caused by his failure to engage in business. ${ }^{44}$ Presumably the broker could claim his percentage of the damages awarded to the landlord in such a suit. ${ }^{45}$ But no court has yet ruled whether the broker whose compensation is based on rental can bring his own action for damages against the tenant when the landlord does not sue. Allowing such a suit would torture third party beneficiary doctrine. ${ }^{20}$ And the tenant's failure to do business, coupled with the landlord's failure to sue, indicates that the value of the lease relationship has deteriorated. In these circumstances, the broker should not be permitted to recover from the tenant.

\section{EXTENSION OF THE LEASE TERM}

Leasing parties frequently extend their relationship beyond the term for which they initially bound themselves. ${ }^{47}$ Extensions may be contemplated in

42. Such leases are known as "percentage leases." MICMIrcran, op. cil. sugra note 7 , at 21. But percentage leases do not always base rent upon gross sales. See id. at 29-30 (net earnings over minimum amount); BenNetr, Law of LANDLaRn AND TE:asis, App. XI (1939) (1 cent per gallon). The great advantage of a well drawn percentage lease is that it automatically adjusts rent to changes in the leasing parties' economic conditions. MCNIICHAEL, op. cit. supra, at 23-4.

43. Many percentage leases guarantee the landlord a minimum fixed rent. Unless the brokerage agreement conditions payment upon the receipt of rent, the broker will be paid compensation based on the minimum rent when the lease is closed and will receive additional compensation in any year in which the tenant pays more than the minimum. But many big chains today rent on a straight percentage basis, with no minimum rent at all. INTERVIEWS.

A brokerage contract which calls for payment of commissions more than one year in the future may come within the provisions of the statute of frauds. See note 74 infro.

44. Hughes v. Robinson, 60 M1o. App. 194 (1895) ; Goldberg 16S-05 Corp. v. Levy, 170 Misc. 292, 9 N.Y.S.2d 304 (Sup. Ct. 1938), modified, 256 App. Div. 1086, 11 N.Y.S.2d 315 (2d Dep't 1939) ; Marvin Drug Co. v. Couch, 134 S.W.2d 356 (Tex. Civ. App. 1939), 25 CorNell L.Q. 615 (1940) ; Note, 16 N.Y.U.L.Q. Rev. 284 (1939). Contra: Cousins Inv. Co. v. Hastings Clothing Co., 45 Cal. App. 2d 141, 113 P.2d 878 (1941). The parcentage lease may include an express covenant embodying the tenant's promise to do business. See Friedman, Proparation of Leases in Practicing LAw Institute, Ge:iendi. Practice Series (No. 2, 1946).

45. The broker's theory will be that the damages were awarded in lieu of rents. Brokers who are compensated under contracts conditioning commissions upon receipt of rent, or sales price, may recover when the landlord recovers damages for a tenant's or purchaser's breach. Haber v. Goldberg, 92 N.J.L. 367, 105 Atl. 874 (1918); Grant v. McLaughlin, 92 Okla. 51, 217 Pac. 873 (1923).

46. Courts verbalize denial of third party enforcement in terms of "incidental beneficiaries." 4 CoRbin, Contracts $\$ 779 \mathrm{C}$ (1951); 2 Willisto:, Cosmucts $\$ 402$ (Rev. ed. 1936). Here the promise to do business is primarily for the landlord's benefit. Eut cf. $61 \mathrm{HARv}$. L. REv. 1054 (1948) (concerning sales).

47. For definitions of extension and rencwals and distinctions between them see 1 
the original instrument. Thus the lease may allow one or both of the parties to lengthen the term by exercising an option to renew or by failing to exercise an option to terminate. ${ }^{48}$ In other instances, the parties may extend their relationship beyond the period anticipated in the first lease arrangement. This can be accomplished by rewriting the original agreement to make it run for an additional period, ${ }^{49}$ or by negotiating a new lease with different provisions. Any such extension evidences the continued value of the lease relationship.

In no case is the broker entitled to remuneration attributable to extension of the lease term until such an extension actually occurs."00 Under an "if, as, and when" agreement the broker can claim only his percentage of each rent payment as it is made. ${ }^{51}$ And under the "ready, willing, and able" doctrine "52 the broker's compensation at the time of closing is measured only by the rent which the tenant has unconditionally obligated himself to pay. ${ }^{\text {es }}$

AMrerican LAw of Property $\$ 3.85$ (Casner ed. 1952); Note, 172 A.L.R. 1205 (1948). The terms will be used interchangeably in this comment. For general coverage of the problems raised by lease extension, see BENNETT, op. cit. supra note $42, \$ \S 102-112$ (1939).

48. Because of uncertainties in business future, businessmen may not be willing to assume a lease obligation for as long a term as they hope to use the premises profitably. But especially if the location is an element of their good will, or if moving their business activity to another location involves great expense, they may desire the power to extend the lease relationship. When the original lease expires, business may be good. For an example of such a lease, see MCMichaEL, op. cit. supra note 7, at 298.

49. There are several ways of achieving this result. A document identical with the original lease save for dates may be executed. Or an agreement may be drawn between the parties providing that they shall be bound by the provisions of the lease for an additional time period. Or the tenant may merely remain in possession with the landlord's consent and continue to meet the obligations of his tenancy. By holding over, however, the tenant obligates himself for a term identical with that provided in the original lease only if the rent expressed therein was the total amount due for the entire lease term. See 1 American Law of Property \$\$3.33-3.35 (Casner ed. 1952).

50. If the lease sets a term but gives the tenant an option to terminate at an earlier date, the broker may occasionally receive commissions for the entire term. If the tenant terminates, the broker must return the payment to the extent that it represents commissions on the rental payments forestalled by the termination. See, e.g., Laughlin $v$. Terry, 1.10 S.W.2d 838 (Mo. App. 1937). Although in such a case the broker originally receives his commissions for the renewal period, he has no unconditional right to them until the extension is actually made.

51. See page 669 supra.

53. E.g., Laughlin v. Terry, 110 S.W.2d 838 (Mo. App. 1937). Leases may permit the parties to terminate upon the occurrance of conditions over which they have no control-fires, for instance. See Lewis, Law of Leases of Reat Property 393 (2d ed. 1930). As yet no court has held that the "ready, willing, and able" doctrine requires that payment of commissions be deferred until the non-occurrence of such events is assured. But if the parties to the lease had some control over the condition such a result might be plausible. See, e.g., Goldberg 168-05 Corp. v. Levy, 170 Misc. 292, 9 N.Y.S.2d 304 (Sup. Ct. 1938), modified, 256 App. Div. 1086, 11 N.Y.S.2d 315 (2d Dep't 1939) (tenant opened another store to compete with one on leased premises, in order to terminate lease by reducing sales below minimum rental specified). 
Nevertheless the broker may collect additional commissions at some time after the lease term is extended. ${ }^{54}$ If his contract expressly calls for added compensation upon an "extension or renewal of the lease," he can frequently" recover. ${ }^{55}$ At least one early court held such a contract provision unenforceable. According to that decision, the broker played no part in effecting the extension, and hence there was no consideration for the promise to pay him an additional commission. ${ }^{\text {be }}$ But such reasoning is not persuasive. Even if the broker does not perform new services by cajoling a reluctant party into an extension, the parties themselves-by choosing to extend the leaseindicate that the term for which they had bound themselves understated the value of the relationship which the broker originally created. Feeling that the broker deserves an added fee, courts now reason that such payment is merely part of the consideration for the services which the broker originally rendered. ${ }^{57}$ And where the extension made was contemplated by an option in the original lease, courts sometimes avoid the consideration problem completely. They hold that the extension merely transformed the original lease into a lease for a longer term. ${ }^{58}$

Even where a court finds consideration for an "extension or renewal" provision in a brokerage agreement, the broker will succeed only if the court holds that the contracting parties intended that provision to cover the particular extension for which the broker seeks recovery. Where the parties to a lease devoid of options rewrite the lease to make it run for an additional period, a general provision in the brokerage contract for added compensation upon extension will probably support a claim; denying recovery in such a case would

54. If the broker's contract was governed by the "ready, willing, and able" doctrine, a commission for the period of the renewal would become due as soon as the tenant renewed. But if the broker's contract provides for commission payments "if, as, and when" rents are received, any commissions sought under the contract after a renewal would become due only as the tenant paid rents.

The broker may also seek additional commissions when the tenant excreises an option to purchase the premises. Like a renewal, such a purchase usually evidences the success of the lease. Many of the problems raised by such purchase do not differ from those encountered in the lease extension situation. Hence, recommendations relating to extensions apply to a purchase by the tenant.

55. E.g., E. O. Bailey \& Co. v. Union Planters Title Guaranty Co., 33 Tenn. App. 439, 232 S.IW.2d 309 (1949). See SchWartz, op. cit. supra note 10, §47.

56. Allwin Realty Co. v. Barth, 161 App. Div. 568, 146 N.Y. Supp. 960 (1st Dep't 1914). However, the court conceded that the rule might be different where an option was exercised. No additional services, such as persuasion, need be given where the original instrument contemplated extension. Cf. text at note $\mathbf{5 8}$ infra.

57. Williams v. Heckscher, 126 Misc. 176, 212 N.Y. Supp. 685 (1st Dep't 1925); E. O. Bailey \& Co. v. Union Planters Title Guaranty Co., 33 Tenn. App. 439, 457-8, 232 S.W.2d 309, 317 (1949). See also F. Bruce Maiden \& Co. v. Lippow, 94 Cal. App. 2d 140, 210 P.2d $\& 2$ (1949).

58. Johnson v. McLean, 19 So.2d 581 (La. Ct. App. 1944) ; Bashein v. 2682 Broadway, Inc., 179 Miisc. 1040, 39 N.Y.S.2d 137 (City Ct. 1942). 
give the contract provision no effect. ${ }^{59}$ In addition, courts will interpret such a provision as embracing an extension made as contemplated in the original lease-either through exercise of an option to renew or failure to exercise an option to terminate. ${ }^{60}$ It is reasonable to suppose that "extensions" as used in the broker's contract was intended to refer at least to extensions which the renting parties anticipated in writing the original lease. But where a lease containing options is extended beyond the period provided for by options, courts deny recovery, interpreting the term "extensions or renewals" in the brokerage contract as intended to cover only renewals anticipated by the options. ${ }^{61}$ In this situation the intent of the contracting parties is certainly ambiguous. ${ }^{62}$ If the broker wants to collect for extensions beyond those provided for in the original lease, he should write into his contract an explicit provision to that effect. ${ }^{63}$ Since he is generally in a position to draw the brokerage contract, ${ }^{64}$ it would impose no great hardship upon him to require specific statement. ${ }^{65}$

A more delicate problem of interpretation arises when the leasing parties, foregoing their opportunity to rely on options or to rewrite the orginal agreement, extend the relationship by executing a new instrument with provisions different from those of the original. According to property law definition such a contract is not a "renewal" of the original lease. 60 Despite this fact,

59. Where the lease contains no option, the parties cannot renew except by extending the lease beyond the terms originally contemplated. Hence, the word "renewal" in the brokerage agreement can refer to nothing except such an extension.

60. Williams v. Heckscher, 126 Misc. 176, 212 N.Y. Supp. 685 (1st Dep't 1925); Bashein v. 2682 Broadway, Inc., 179 Misc. 1040, 39 N.Y.S.2d 137 (City Ct. 1942). See Scewartz, op. cit. supra note $10, \S 47$.

61. E.g., Zuzak v. Querbes, 193 So. 208 (La. Ct. App. 1939).

62. Another ambiguity which brokerage contracts should resolve arises when a lease expires and a period of time elapses before renewal or purchase is made. Some contracts meet the problem by specifying that the broker shall collect for any extension made within a specific time. See, e.g., Comly v. First Camden National Bank \& Trust Co., 22 N.J. Misc. 123, 36 A.2d 591 (Sup. Ct. 1944) ("any new lease made within one year of the expiration hereof"). If no time limit is specified, a lapse of time between expiration of the original lease and renewal may prevent the broker from recovering additional com. missions. See Odell v. Wessinger, 54 Ga. App. 838, 189 S.E. 367 (1936); Sheild v. Welch, 4 N.J. 563, 73 A.2d 536 (1.950).

63. See E. O. Bailey \& Co. v. Union Planters Title Guaranty Co., 33 Tenn. App. 439, 443,232 S.W.2d 309, 311 (1949) ("for any subsequent lease that may be entered into by the Lessor with the Lessee covering the within leased premises"). For a contract clearly limiting the broker's recovery to renewals provided for by lease options, see Hirshaut v. Ace Hotel Corp., 270 App. Div. 314, 59 N.Y.S.2d 758 (3d Dep't 1946) ("for the two renewal periods mentioned therein").

64. The brokerage contract is usually drawn by the broker. InTERviews. Often it is a form signed at time of listing. See note 2 supra.

65. See Smith, The Florida Real Estate Broker and his Commission, 3 Misu1 L.Q. 424, 431 (1949).

66. For a compilation of opinions defining "renewal," see Note, 172 A.L.R. 1205 (1948). Such a definition has been used in brokerage contract cases. See Mitchnik v. 
however, some courts permit the broker to recover where the new lease is substantially similar to the original one. ${ }^{67}$ The rationale is that denial of recovery would permit the leasing parties to defraud the broker of his commission merely by substituting a new piece of paper. ${ }^{68}$ But where the change in the lease seems more than a mere sham, the broker's claim has been rejected.cs The existence of a valid business purpose for the change may well induce denial of recovery. ${ }^{70}$ And in some cases the lease contemplated extension by providing options, but the parties choose instead to execute a new lease calling for a lower rental or a term shorter than that specified by the options. Faced with such a situation courts have reasoned that there has been no "renewal" and hence the broker's contract does not entitle him to additional compensation. ${ }^{71}$

When leasing parties extend their relationship by executing a new instrument, courts should not be overly restrictive in interpreting "extension or renewal" in the brokerage contract. The bare fact that the lease relationship has been preserved indicates that it has achieved some meastre of successthe standard by which the broker's commission is generally determined. ${ }^{72}$ Whereas parties will probably not discontinue their leasing arrangement solely to guard against an added brokerage commission, they might well choose to substitute a new instrument for that purpase. And the terms of the lease can often be changed to look quite different without making a substantial change in either party's economic status. ${ }^{73}$

Questions relating to the broker's rights upon extension are not limited to cases where the broker has expressly contracted for commissions upon extension. If he is not barred by the statute of frauds ${ }^{74}$ a broker who has

Brennan, 159 Misc. 287, 286 N.Y. Supp. 609 (Munic. Ct. 1936); Sheild v. Welch, 4 X.J. 563,73 A.2d 536 (1950).

67. Hirshaut v. Ace Hotel Corp., 270 App. Div. 314, 59 N.Y.S.2d 758 (3d Dep't 1946); Rosenblum v. Lurie, $128 \mathrm{~Pa}$. Super. 480, 194 Atl. 204 (1937). Contra: Harris v. Buckeye Sheriff Street Realty Co., 35 Ohio Law Abstract 373, 40 N.E.2d 949 (Ct. App. 1941).

68. E.g., Zuzak v. Querbes, 193 So. 258 (Ia. Ct. App. 1939).

69. Ernest A. Carrere's Sons v. Levy, 191 So. 747 (La. Ct. App. 1939) (alternative holding); Harris v. Buckeye Sheriff Street Realty Co., 35 Ohio Law Abstract 373, 40 N.E.2d 949 (Ct. App. 1941) semble.

70. See, e.g., Harris v. Buckeye Sheriff Street Realty Co., 35 Ohio Law Abstract 373, 40 N.E.2d 949 (Ct. App. 1941).

71. Ibid. See Masten Realty Co. v. James, 125 N.J.L. 529, 16 A.2d 464, 465 (Sup. Ct. 1940). Contra: Rosenblum v. Lurie, 128 Pa. Super. 4\&0, 194 Atl. 204 (1937).

72. See page 666 supra.

73. See page 678 infra.

74. The broker's ability to enforce his commission claim may be limited by a statute of frauds provision requiring that contracts to be performed in more than one year must be in writing. 2 CoRBIn, CoNTRACTs $\$ 474$ (1950). Courts have generally construed the statute as applying only to contracts which could not be performed within one year. Hence brokerage agreements which provide for additional commissions upon the exercise of an option to renew do not come within the statute if the option may be exercised 
no express contract with the leasing parties may claim added compensation. Recovery for extensions in such an event depends on whether the local Real Estate Board rules, invariably read as barometers of reasonable or customary compensation, authorize commissions upon extension. ${ }^{75}$ Board rules in some cities sanction an additional fee either upon the exercise of an option to renew or on failure to exercise an option to terminate. ${ }^{76}$ Some boards also atthorize commissions upon non-optional renewals of the lease. ${ }^{77}$

On the whole courts have been hesitant to permit brokers to recover commissions attributable to lease extensions. This judicial animus apparently stems from a fear of spawning infinite or near-infinite series of commission recoveries. ${ }^{78}$ In theory at least, a successful relationship might be extended forever $^{79}$ Permitting the broker to recover for extensions made decades after the leasehold's inception not only would saddle the relationship with an expense far beyond the original parties' expectations, ${ }^{80}$ but might also allow

within one year. Bashein v. 2682 Broadway, Inc., 179 Misc. 1040, 39 N.Y.S.2d 137 (City Ct. 1942); Williams v. Heckscher, 126 Misc. 176, 212 N.Y. Supp. 685 (1st Dep't 1925). But the agreement must be in writing if the amount of the broker's additional commission cannot be determined within one year-as where he collects upon a percentage lease, Jaffe v. New York Towers, 108 N.Y.S.2d 193 (City Ct. 1951), or upon an extension the rental for which is to be set by an appraisal, Mullen \& Woods v. 615 West 57th Street, 144 Misc. 697, 259 N.Y. Supp. 250 (Munic. Ct. 1932), revid on other grounds, 146 Misc. 599, 262 N.Y. Supp. 467 (Sup. Ct. 1933).

In many instances, of course, the broker will attempt to collect on a contract which is written, but which is mute on the effect of a renewal. In such a case, the statute of frauds should be no problem. Allowing the broker to recover is merely a matter of enforcing the written contract according to the parties' contractual intent; it is not allowing enforcement of an oral agreement. But $c f$. Schulz \& Co. v. Realty Associates, 17 N.Y.S.2d 924 (Munic. Ct. 1940).

75. See Johnson v. McLean, 19 So.2d 581 (La. Ct. App. 1944); but cf. Schulz \& Co. v. Realty Associates, Inc., 17 N.Y.S.2d 924 (Munic. Ct. 1940) (general brokerage contract not calling for commissions upon renewal, and an option in the lease for the tenant did not support a suit for additional commissions). Granting that no problem of consideration is raised in the attempt to recover additional compensation, see pagc 673 supra, the applicable legal principles should be no different from those applying to any contract in which the compensation is not stated, or is stated ambiguously. Sec note 18 supra.

76. See, e.g., rules for Buffalo, New York (option to renew), and Chicago, Illinois (tenant's option to cancel), in MCMrChAEI, op. cit. supra note 7, at 548, 551.

77. See, e.g., rules for Philadelphia, Pennsylvania; Los Angeles, California. Many board rules merely state that commissions are payable on "renewals." See, e.g., Brooklyn, New York; Columbus, Ohio. The New York City rules suggest a written agreement stipulating additional commissions for renewals. Id. at 547-52.

78. See, e.g., Mitchnik v. Brennan, 159 Misc. 287, 286 N.Y. Supp. 609 (Munic. Ct. 1936).

79. Leases providing for perpetual renewals, for example, are valid. BENNETr, op. cit. supra note $42, \S 106$.

80. It may be difficult to distinguish between increases in the value of the landlord's interest which result from the broker's leasing of the premises, and those which result from other factors. But except for the transaction in which a particular use creates its 
recovery against a leasing party wholly unaware of his liability on a contract made years before. ${ }^{81}$ Although continued brokerage recoveries may be theoretically justifiable, ${ }^{82}$ brokers' insistence on receiving commissions as long as extensions are made seems certain to prejudice their chances of recovering for any renewals at all. Brokers should therefore bow to judicial bent. Contracts can be written to put a time limit on commission recoveries. ${ }^{83}$ To cope with cases in which the broker's contract contains no such limitation or where the broker has no express contract, Real Estate Boards should adopt rules putting a time limit on commission recoveries. ${ }^{84}$ Board rules would provide "reasonable" or "customary" limits for courts to read into ambiguous or implied contracts. And they would go far toward giving land holders and their lawyers warning that continued brokerage commissions are possible unless expressly denied by contract.

\section{Renegotiation of Lease Provisions}

Changes in economic conditions and business needs may lead to a voluntary renegotiation of the renting agreement during the lease term. ${ }^{85}$ If the broker's compensation is governed by the "ready, willing, and able" doctrine courts view the brokerage contract as a simple employment contract. ${ }^{80}$ Hence altera-

own "neighborhood," for instance, where the erection of a large department store assures a shopping district, changes in the value of a location should not accrue to the broker's benefit.

81. Cf. Heard v. Miles, 32 Tenn. App. 410, 222 S.W.2d 848 (1949), where the court refused enforcement of the broker's claim for additional commissions upon a sale to the tenant, on the ground that the broker breached his "fiduciary" duty of notifying the owner before the sale was consummated of the broker's right to compensation.

82. See page 686 infra.

83. Such a limitation need not be formulated in terms of options in the lease as in the Hirshaut case, supra note 63 , but may also be stated-perhaps with less ambiguityif it simply limits the broker's commission to a percentage of rentals payable before a certain date.

84. Some Board rules already limit the broker's recovery. See rules for Philadelphia, Pennsylvania (commissions for renewals limited to 5 years, or the length of the original lease, whichever is longer); Dallas, Texas (same); Chicago, Illinois (amount limited in relation to first year's rent) ; San Francisco, California (commissions limited to amount broker would have collected if premises sold), cited in $M[C \lambda[x C E A E z, 0 p$. cit. supra note 7 , at 546-53.

85. The term "renegotiation" is used here to include agreements between the landlord and tenant to rescind the old lease and write a new agreement, and mere failure on the part of the landlord to enforce terms of the old lease. On rescission and modification of leases, see NEW YORK LAW OF LANDLORD AND TENANT, \$963 et seq. (Thompson, Edward, Co. ed. 1937) ; BENAEIT, op. cit. supra note 42, §§ 14, 37 et seq. (1942).

"Renewals," which result in continuation of the landlord and tenant's relationship beyond the original term, can only arbitrarily be separated from renegotiation-changing the provisions of the lease relationship during its term. A single reformation of the landlord-tenant relationship may result in both. See, e.g., Zuzak v. Querbes, 193 So. 258 (La. Ct. App. 1939).

86. See notes 10 supra and 87 infra. 
tion of the lease will not affect the broker; he already has an unconditional right to commissions based on the total rents payable under the original agreement. $^{87}$ But if the broker has contracted to receive compensation only "if, as, and when" rental is paid, his commissions will be adjusted in accordance with changes in the lease. ${ }^{88}$

Computing the broker's commission under an "if, as, and when" contract may be difficult when renegotiation of the lease has changed the kind of consideration passing to the landlord. To take a simple example, suppose that the tenant originally promised to make rental payments in cash to the landlord. After renegotiation the lease calls for the same cash payments, but the tenant also assumes the landlord's obligation to pay taxes on the property. Clearly each tax payment made by the tenant is part of the new "rental." Under the new arrangement the tenant pays more for his occupancy, and the landlord realizes more net income from the property. The broker's commissions after the renegotiation should be computed as a percentage both of the cash payments and of the tax payments. ${ }^{80}$ But other situations do not seem as clear. Stupposc that the original lease called upon the tenant to make cash rental payments and also to pay water, electricity, and other utilities charges. The landlord paid the broker a percentage of cash rentals received. ${ }^{90}$ Upon renegotiation the tenant agrees to pay larger cash rentals, while the landlord agrees to pay the utilities charges. It would seem unfair to allow the broker to collect his percentage computed on the entire cash payments, since the landlord has assumed an additional expense. On the other hand, if the landlord is allowed to deduct one expense before computing the broker's post-renegotiation commission, courts might be tempted to allow him to deduct other expenses as well. If so the broker would be paid only a percentage of the landlord's net income -a result not reflecting the value of the new relationship and hardly contemplated by a contract calling for a percentage of "rentals."

87. The broker is entitled to his commission when his part of the brokerage contract is performed. Typically, his performance merely requires finding a tenant "ready, willing, and able" to lease the premises. See note 10 supra. His contract may recuuire less. Cf. Mechem, The Real Estate Broker and His Commissions, 6 ILL. L. Rev. 145, 238, 313 (1911-1912). It may require more. See page 669 stipra and note 88 infra. But if the tenant is completely unable to meet his lease obligations, this might affect the initial finding of the broker's performance-finding an able tenant. WALKER, op. cit. supra noto $1, \S 221$.

88. See, e.g., Davis v. Nichols, 124 S.W.2d 881 (Tex. Civ. App. 1939).

89. Since the total amount of future tax payments probably cannot be accurately computed, the broker will either have to postpone collection of his commission, or agree to take an amount based on an estimate of future taxes. Real Estate Boards which suggest that lessee-paid taxes be included in total rents recommend the latter solution. Sce Real Estate Board of New York, Commission Rates and Rules Rule 7 (1952)' (current year's taxes used unless new construction involved). See also rules for Indianapolis, Indiana, cited in MCMICHAEL, op. cit. supra note 7, at 549.

90. This is the typical arrangement. But sometimes non-cash items are included in total rent. See, e.g., note 89 supra.

91. If a determination of the meaning of the term "rentals" in the original brokerage 
These two examples serve to suggest some of the problems which may arise in determining what constitutes the "rental" of which the broker is to receive a percentage after renegotiation. In addition, problems of evaluating non-cash items may be encountered. ${ }^{92}$ The provisions which may be written into a lease and then shuffled in a renegotiation are legion. ${ }^{03}$ Any attempt to formulate a comprehensive definition of "rental" would be quixotic. But courts should not limit that term to cash payments made directly by tenant to landlord. Rather, in figuring the broker's commission, they should determine what real economic change the renegotiation has wrought. In each case judicial conscience should be the guide.

If the tenant's use of the leased premises has been successful, renegotiation may entail the leasing of additional premises. The broker will probably collect no commission for such an extension unless he has specifically contracted for such a contingency. ${ }^{94}$ Even an explicit contract calling for commissions upon expansion may present difficulties. If the agreement specifically refers only to expansion of the original lease, the parties may forestall the broker's claim by executing a second lease for the additional property. Ind a contract drawn broadly enough to embrace new leases of any additional property may run afoul of judicial dislike for theoretically limitless recoveries.5 Such an agreement might be deemed an attempt by the broker to collect a commission upon any second lease between the same parties and involving land in the vicinity-whether or not contiguous with the original premises. Even if brokers never made such an extreme claim, general language might result in recovery for leases not directly a product of the original lease's success. The most equitable and easily administered solution would apparently be to deny the broker recovery for new leases of additional premises unless he has ex-

contract were involved, the question to whose benefit the landlord's expenditure accrued might be relevant. See Loeb v. Viviano, 202 S.W.2d 528 (JIo. App. 1947) (cash payments used by landlord for improvement of premises held not "rent"). But here the only issue is how to adjust the broker's commission, which is to be computed from a certain base, when the elements that make up that base have been changed. It is submitted that here only the utility charges should be deducted from total rentals.

92. See note 89 supra. Other non-cash items may require evaluation. Where the lessee erects an improvement its value may be added to the total rentals. But valuation of the improvement may entail complexities. The improvement may be made for the sole benefit of the tenant, and may be valueless at the end of the lease term. But the improvement, even in that instance, may be of value to the lessor as security. Nreuv'ss \& FISmEr, ap. cit. supra note 4 , at 23 .

93. Some of the provisions most commonly included in leases are: payment of taxes, insurance, making of repairs, and improvements. See BENwErT, op. cit. sufra note 42, Apps. I, II, VIII. For an example of reshuffling see, Ernest A. Carrere's Sons v. Lery; 191 So. 747 (La. Ct. App. 1939).

04. For an example of such a contract see E. O. Bailey \& Co. v. Union Planters Title Guaranty Co., 33 Tenn. App. 439, 232 S.W.2d 309 (1949).

95. See page 677 supra. Courts might formulate their objections in terms of failure of consideration. See page 673 supra. 
pressly written into his contract a provision naming individually the piece or pieces of adjacent property for the rental of which he will be compensated.0

\section{Transfer of Interests in the Leased Realty}

The long-term nature of modern business leases makes it likely that, at some time during the term, the party who originally contracted to pay the broker will transfer his interest to another-by assignment, gift, or descent. ${ }^{07}$ And payment of the broker's commission for creating such a lease is often deferred. ${ }^{88}$ A broker may, therefore, seek commission recoveries after the original parties to the lease have passed their interests to transferees. Few cases have been reported which deal with brokerage claims in this context. And deduction from doctrinally analogous cases yields no sure clue to future clecisions. Such uncertainty troubles brokers who hold contracts calling for further commissions upon continuation or extension of lease relationships currently in existence. ${ }^{\text {go }}$

If, after a change in parties to the lease, the broker's compensation is not paid, he can bring a contract action against the party who originally promised to pay him. ${ }^{100}$ But such a suit may be brought only after a breach, ${ }^{101}$ and then only for damages already suffered. ${ }^{102}$ To recover continuing commissions

96. In certain cases this solution might produce difficulties. If, for example, a lessee whose rental is measured by gross sales leases additional selling space, merely agrecing to pay the same percentage of the anticipated rise in sales, computation of the broker's commission might entail additional accounting problems.

97. This may not be true in the case of institutional landlords. See note 4 supra. But it is true of individual landlords and of most business tenants, whether incorporated or not. See Comment, 48 YaLE L.J. 1400, 1411 (1939). For a general discussion of the problems relating to transfer of leasing parties' interests, see BENNETr, op. cil. supra nate $42, \S \S 276-8,283-6$.

98. See page 669 supra.

99. INTERVIEWS.

100. The broker's claim is a contract claim and not an interest in property. Sec page $\mathrm{xxx}$ infra. Hence, transfer by a landlord or tenant of the duty to pay the broker does not extinguish the transferor's obligation. 2 Williston, Contrucrs, $\$ 411$ (Rev. ed. 1936).

101. Breach generally will consist of non-payment of commissions when they become due. In many jurisdictions no action can be based on an anticipatory breach when the plaintiff has fully performed his part of the contract. 5 WiLliston, ContRActs, $\$ 1296$ (Rev. ed. 1936). Such a rule would exclude most broker's claims. But the better rule is not to deny actions for anticipatory breach to parties who have fully performed. 4 Conms, CoNTRACTS, $\S 962$ (1951). However, since an action based on an anticipatory breach requires a clear and unequivocal repudiation, $i d . \S 973$, brokers are unlikely to be able to utilize this remedy, especially since an assignor's repudiation does not necessarily mean an assignee will not perform.

102. See Manufacturers' Furniture Co. v. Read, 172 Ark. 642, 290 S.W. 353 (1927). However, the broker might be able to prove anticipatory breach of future obligations on the basis of the breaches which have already occurred. See note 101 supra. But if future compensation depends upon the contingency of the tenant's paying rent or renewing, recovery might be denied either on the ground of the uncertainty of the breach, or the 
in this manner the broker must embark upon a series of suits against a person who may have withdrawn from the lease relationship long ago ${ }^{103}$-and who may be presently unavailable or financially irresponsible.

The broker frequently seeks to obviate the necessity for recurrent suits by writing into the original brokerage contract an "acceleration" clause. ${ }^{102}$ In such a provision the promisor agrees that if he transfers his interest in the leased property, he shall pay the broker a specified lump sum. ${ }^{105}$ Thus the promisor becomes liable as soon as he leaves the lease relationship-a time when he is available and when his funds may be augmented by the proceeds of sale. ${ }^{106}$ But in order to replace continuing commissions, the liquidated damage provision must grant the broker a healthy sum. The party employing the broker may refuse to sign such a contract. The size of a single cash payment may be prohibitive. In addition, the promisor may object to paying an amount computed on the supposition that the lease relationship will continue to be successful when later events may indicate a lack of success. ${ }^{107}$ Conversely, the broker may object to a sum based on the equally arbitrary supposition that the success of the relationship will diminish.

In view of the difficulty the broker may have in collecting from the original promisor, he frequently must look for his commissions to the transferee who has succeeded to the original promisor's interest. But the transferee is not bound to perform the brokerage contract unless he actually or constructively consents to do so. ${ }^{108} \mathrm{~A}$ recital in the brokerage contract that it shail bind successors and assigns is not enough to make the transferee liable -even when the transferee knows of the brokerage contract and the broker's

uncertainty of the plaintiff's damages. See Manufacturers' Furniture Co. v. Read, suspra. Cf. Mabery v. Western Casualty \& Surety Co., 173 Kan. 586, 250 P.2d 824 (1952). But cf. 5 CoRBin, Contracts $\$ 1025$ (1951).

103. Breach may not occur until long after the original promisor withdrew from the relationship. For example, the original landlord's interest may be transferred to another. The broker may seek a commission only years later, upon the tenant's renewal of the lease or purchase of the property. See, e.g., Heard v. Miles, 32 Tenn. App. 410, 222 S.W.2d 848 (1949). As to the possibilities of suing the transferce in this situation, see pages 681-5 inifra.

104. INTERVIEWS.

105. Instead of a specific sum, the brokerage agreement may call for a payment upon transfer computed, for example, by finding average past commissions and projecting them over the years remaining in the lease. Of course, such a computation does not evaluate the probabilities of renewal.

106. The parties may agree to have the liquidated damage clause apply in the event of the promisor's death. Then funds would not be available from a sale of the interest in realty. But other advantages to such a provision remain. The broker's claim against the estate becomes readily dischargeable. See note 123 infra.

107. See text at note 35 supra.

108. Wood Fabricators v. Hayes, 250 Ala. 475, 35 So.2d 106 (1948); Ernest A. Carrere's Sons v. Levy, 191 So. 747 (La. Ct. App. 1939); Mrasten Realty Co. v. James, 125 N.J.L. 529, 16 A.2d 464 (Sup. Ct. N.J. 1940). 
claim. ${ }^{109}$ Only by introducing extrinsic evidence of consent will the broker be able to hold the transferee. In many cases at least, such independent assent will be non-existent or impossible to prove.

In an attempt to overcome the consent requirement the broker often writes his contract into the lease as a covenant. ${ }^{110}$ If the lease stipulates that it shall bind successors and assigns and if the broker sees that the lease is recorded, ${ }^{\mathbf{1 1 1}}$ perhaps that should be sufficient to make the transferee liable. But under current doctrine recovery seems doubtful. ${ }^{112}$ The promise to pay the broker, though stated in the lease, is treated as a collateral personal covenant granting the broker no interest in the realty. ${ }^{113}$. Hence the covenant must still be enforced on contract rationale. ${ }^{114}$

109. The recital in the brokerage contract is not enough, by itself, to bind the transferee. Since the transferee is not a party to the contract, no consent can be implied from it. See Glenn v. Canby, 24 Md. 127 (1866) (mortgage with similar recital). On the effect of such recitals, see 4 CoRBIN, Contracts $\$ 871$ (1951).

Nor can the transferee's consent be implied from knowledge of the existence of the leasehold. Comly v. First Camden National Bank \& Trust Co., 22 N.J. Misc. 123, 36 A.2d 591 (Sup. Ct. 1944); Masten Realty Co. v. James, 125 N.J.L. 529, 16 A.2d 464 (Sup. Ct. N.J. 1940).

At the time of the assignment of the promisor's interest in the leased realty it is improbable that any further performance by the broker will still be due the party that promised to pay him. See note 2 supra. Hence, there will be no assignment of rights from which to imply the assignee's consent to assume the obligation to the broker. Cases involving the obligation of a mortgagor's assignee to pay the mortgage are analogous. Assumption of the obligation is said to require conclusive evidence of assent. See WiLTS1E, MosTGAGE FORECLOSURES §219 (5th ed. 1939). Inference even from knowledge of the assignment clause in the agreement is doubtful. See Peoples Savings \& Loan Ass'n v. Brinkoctter, 263 I11. App. 391 (1931). Merely by purchasing mortgaged realty, the grantec does not become liable to pay the mortgage indebtedness. The property merely remains subject to the mortgage lien. See WitrsiE, op. cit. supra § 218.

110. INTERviEws. See, e.g., agreement in Bacharach v. Mitnick, 121 N.J.L. 401, 3 A.2d 92 (1.938).

111. Long term leases are recordable in all jurisdictions. 4 AMERICAN LaW of ProperTy $\$ 17.8$ (Casner ed. 1952).

112. Cf. Wood Fabricators v. Hayes, 250 Ala. 475, 35 So.2d 106 (1948); Comly v. First Camden National Bank \& Trust Co., 22 N.J. Misc. 123, 36 A.2d 591 (Sup. Ct. 1944) ; Bacharach v. Mitnick, 121. N.J.L. 401, 3 A.2d 92 (Sup. Ct. 1938).

113. Ernest A. Carrere's Sons v. Levy, 191 So. 747 (La. Ct. App. 1939); Sec also Sheild v. Welch, 4 N.J. 563, 73 A.2d 536 (1950); 4 Corbin, Contracts $\$ 860$ (1951).

114. Recording of the lease probably does not alter the result. The effect of recording an instrument recordable under the recording statutes is to give constructive notice of its contents. It is doubtful whether a separate brokerage contract would be recordable under the statutes. See 2 PoMreroy, Equity JuRisprudence $\$ 646$ (1941). And recordation of an unrecordable interest is not constructive notice to transferces. Sjoblom v. Mark, 103 Minn. 193, 114 N.W. 746 (1908). Moreover, notice of an instrument creating or conveying an interest in realty is not notice of collateral matter contained in the instrument. 2 POMEROY, EQUITY JURISPRUDENCE $\$ 629$ (1941).

However, recording the brokerage agreement with the lease may make a showing of consent easier, as it may result in actual notice to the transferee. 
When the broker's contract appears in the lease he may attempt to argue that the transferee, in succeeding to the original promisor's interest in the realty, succeeded also to the obligation to pay brokerage commissions. In the commonest situation the original landlord has hired the broker and covenanted to pay commissions. There the covenant, although appearing in the lease, may be interpreted as a direct promise to the broker.115 When the landlord later sells to a third party, the purchaser will undoubtedly agree to accept the landlord's property subject to the lease. ${ }^{110}$ Such a sales contract, the broker would argue, constitutes the transferee's promise to the landlord to perform all the obligations which the lease imposes on the landlord, including the covenant to pay brokerage commissions. The broker could seek enforcement on the theory that he is a third-party beneficiary of the sales contract.117 A similar theory could be spelled out where the tenant has hired the broker, covenanted to pay him, and later assigned his leasehold. But because the promise to pay commissions is a collateral personal covenant, ${ }^{118}$ courts may be hesitant to infer the transferee's consent to pay the broker from the agreement to take the property subject to the lease. The broker's right is at least so questionable that litigation is bound to ensue.

In some instances the tenant has hired the broker, but as part of the leasing arrangement the landlord agrees to pay brokerage commissions. ${ }^{110}$ Collecting such commissions from the landlord's transferee will be even more difficult. Absent an express contract, the tenant would have been liable to pay the

115. Courts have talked of a broker's suit against the promisor in such a situation as one by a third-party beneficiary. See, e.g., Tapscott v. AfCVey, 83 N.J.L. 747, 85 Atl. 343 (1912). But since the landlord was obligated to the broker, his promise to pay, even if made to the tenant, is in effect merely a restatement of his direct obligation to the brolser. The promise here is not made for the tenant's benefit, or at his request.

116. The landlord may sell his reversion, and his rights under the lease, including unaccrued rents, separately. One who purchases only the reversion will have no obligations under the lease. Hence it is unlikely that he will assume the obligation to pay the brolier.

117. If an assignment contract contained a specific promise by the assignee to pay a broker to whom the assignor is liable, the broker would be a typieal creditor beneficiary and could enforce the assignee's promise. See Lawrence v. Fox, 20 N.Y. $26 \mathrm{~S}$ (1859). The fact that the broker's claim may be contingent or merely payable in the future would not affect the result. 4 Conbin, Contracts $\$ 787$ (1951); Restatesrent, Co:mtracts $\$ 134$ (1932).

Despite continuing judicial suspicion of third party beneficiary doctrine, the orerwhelming majority of American jurisdictions permit creditor beneficiaries to recover directly against a promisor who agreed with a debtor to pay the beneficiary. 4 Connm, Contracts $\$ 78 S$ (1951). And even those states which repudiate third party beneficiary doctrine permit the beneficiary to bring an equitable creditor's bill against the promisor in aid of the beneficiary's action against his debtor. Id. at 113-114. Where a mortgagor assigns his interest, all states but Miassachusetts have permitted the mortgagee to enforce the promise, made by the mortgagor's assignee to the mortgagur, to assume the burden of the mortgage. 2 Wiluiston, Contracts $\$ 383$ (Rev. ed. 1936). And the lav in Mlass= achusetts is not clear. Ibid.

118. See note 113 supra.

119. See note 12 supra. 
broker. ${ }^{120}$ Hence the landlord's promise to pay, if written into the lease, will be interpreted as a covenant in favor of the tenant. The broker is the thirdparty beneficiary of that promise. He may be permitted to enforce the covenant against the original landlord. ${ }^{121}$ Upon sale of the landlord's interest, the sales contract might be said to incorporate the transferee's promise to perform the brokerage covenant. But courts may hold that only the tenant can enforce the covenant against the landlord's transferee; he-not the broker-is the third-party beneficiary of the sales contract. As to that contract the broker is a beneficiary twice removed: the third-party beneficiary of a covenant in favor of the tenant, who in turn is third-party beneficiary of the transferee's contract to buy. As such, the broker stands in a poor position to enforce the payment of commissions. ${ }^{122}$

Where the transfer of interest in the leased realty is accomplished by gift, bequest or intestate succession there is no assignment or sales contract to be enforced by the broker against the transferee. Under these circumstances the broker must argue that the original promisor had a personal obligation to pay commissions and that the transferee assumed that obligation in taking the property interest. ${ }^{123}$ Tenuous at best, this argument may be treated with severity.

120. See notes 10,14 supra.

121. The broker is a prototype creditor beneficiary. See note 117 supra.

122. Courts suspicious of intricate third party beneficiary claims might refuse enforcement merely by holding that the broker is not in "privity" with the transferce. But, of course, no third party beneficiary is ever in privity with the party he secks to suc. The broker could argue that his plea does not differ from that of a mortgagee who sceks to enforce a promise, made by a remote transferee of the mortgagor, to assume the obligation to pay the mortgage. Such pleas have been upheld wherever all intermediate transferees of the mortgagor promised to pay the mortgage. 2 WiLLISTON, ConTzucts $\S 386$ (Rev. ed. 1936). In both situations, the plaintiff (broker, mortgagee) sues a defendant (landlord's assignee, remote assignee of the mortgagor) on a promise made to another (landlord, intermediate mortgagor) who in turn had promised the plaintiff's debtor (tenant, mortgagor) to pay the obligation.

Nor does allowing the broker's claim in this situation make a promisor liable to more than the two parties usually involved in a third party promise-the promisee and the third party beneficiary. And the broker is a creditor beneficiary of the assignee he seeks to stue. Hence, no extension of third party beneficiary doctrine is really necessary in order to permit the broker's recovery.

123. Of course, if the successor agrees to pay the broker, he can be held. See note 108 supra. But if no consent can be shown, the broker may nevertheless have a remedy. At the death of the promisor, his estate becomes liable for the broker's commission. Lyne v. Warriner, 44 So.2d 811 ( $F l a .1950$ ). If the broker proves an unmatured claim against the estate, the administrator may pay him, set up a fund to cover his claim, or get heirs to give a bond securing payment of the obligation when it becomes due. Atrinson, Wrus 699 (1953). If the broker's claim is contingent, however, such treatment by the promisor's administrator may not be feasible. In such a case, courts often permit liquidation of the estate, without disposition of the claim. A subsequent suit against any heir is then allowed. See cases cited $i d$. at 802 . For a discussion of whether a contingent claim will be barred if not filed within the period of administration, see id. at 700-02. 
Apart from doctrinal deficiencies, writing the brokerage contract into the lease may be infeasible. The leasing parties may refuse to sign an instrument containing such a promise. Some fear that a covenant to pay the broker may establish an encumbrance on the realty. Or they may simply feel that such a proviso, because it leaves the liability of assignees in doubt, will constitute an obstacle to free transfer. Although such views may be over-cautious, they have caused leasing parties to keep brokerage covenants out of some leases. ${ }^{104}$

In addition to creating the lease relationship, the broker may contract with the landlord to manage the leased premises and collect rent. ${ }^{125}$ In Pennsylvania the broker's ability to get commissions from a transferee is assured when he holds such a management contract. Pennsylvania courts hold that in entering the contract the landlord assigned to the broker a "vested right" to unaccrued rental. ${ }^{128}$ When the landlord later transfers his interest in the leased premises, he gives his successor only his reversion, his rights and duties not connected with collection of rents, and a contract right to receive from the broker rental payments minus brokerage commissions. Even without the transferee's consent, the broker can keep his commissions as rent is paid.127 But the "vested right" doctrine may curb efficient use of the realty. The broker's "vested right" to rentals deprives the landlord and tenant of their capacity to alter or cancel the lease without the broker's approval. ${ }^{123}$ The doctrine secures the broker's claim, but only at the cost of flexible land use.

The broker's enforcement problems can be avoided also by giving the broker part ownership of the property in lieu of commissions. The broker then would have a perpetual right to share in the property's earnings and in the

124. INTERVIEWS.

125. For a description of activities involved in professional management of real estate, see Benson \& North, Real Estate Principles axd Practices 272-80 (Rev. ed. 1938).

126. Heymann v. Fourth Dickerson Building Ass'n, $113 \mathrm{~Pa}$. Super. 26, 171 Atl. 482 (1934) ; Taylor v. James, 36 Del. Co. Rep. 39 (Pa. Comm. Pl. 1949). In each of these cases, the broker had the duty of collecting rents. He took his commission out of the rents collected.

127. The Heymann and Taylor cases held that under the brokerage agreement, the broker was assigned the right to the unaccrued rentals as security for his commissions; hence, the landlord could no longer assign the right to another and the brolker could not be deprived of his "property right" to collect rents and retain commissions thereirom. Heymann v. Fourth Dickerson Building Ass'n; Taylor v. James, supro note 120. Typically, contracts for collection merely create an agency relationship, even if the agent has the right to take his commissions from the collected funds. See Miecues, op. cit. sipro note $2, \$ 69$.

128. The right to collect accrued rentals is security for the broker's commission. Heymann v. Fourth Dickerson Building Ass'n, supra note 126. MTortgagees who have a right to collect unaccrued rentals as security for mortgage payments an prevent renegotiation of the mortgage. See Landberg v. Equitable Investment $C_{0 .}, 292 \mathrm{~Pa}_{2} 476$, 141 Ati. 302 (1928) ; Mercantile and Theatres Properties, Inc v. Stanley Co., $346 \mathrm{~Pa}$. 343, 30 A.2d 136 (1943). The court in the Heymann case rested its decision on the Londberg case. Heymann v. Fourth Dickerson Building Ass'n, sipra note 125, at 30, 171 Atl. at 483 . 
proceeds of any sale. ${ }^{120}$ But landholders are reluctant to split the fee interest, because multiple ownership seriously hampers alienation. ${ }^{130}$ Fee ownership could be kept intact if a corporation were formed to hold the property. The broker could participate in earnings by holding stock, while the owner could alienate his interest freely by selling his own shares. But funneling earnings through a corporation subjects them to double taxation ${ }^{131}$-a high price for the owner to pay merely for the broker's benefit. Whether the fee interest is split or the property held in corporate hands, real estate owners may well object to a device which grants the broker a permanent right to share in earnings, even after the expiration of the lease relationship which the broker created. For these and a multitude of other reasons less clearly defined, many owners do not want to dilute their ownership interests. ${ }^{132}$

\section{Critique of Existing Remedies}

The transfer by a leasing party of his interest in the property is not an appropriate occasion upon which to sacrifice the broker's ability to collect commissions. Such a transfer does not reflect a decrease in the value of the lease relationship. It therefore should not cut off the remedies by which the broker can collect for his services.

To be sure, the broker can always sue the party who originally promised to pay him. ${ }^{133}$ But that right is hollow when the original promisor is financially unsound or cannot be found. Furthermore, forcing the broker to seek recovery from one who has departed from the lease relationship seems inequitable. Brokerage commissions should be deemed a part of the continuing cost of occupying or owning income-producing property. Such expenses should be paid by a party currently enjoying the benefit of the lease. Both in order to grant the broker an effective remedy and to apportion fairly the expense of brokerage commissions, the broker should be allowed to recover from the transferee of the original promisor.

129. It is also possible expressly to assign the broker the interest which the Pennsylvania courts impute to him when a management contract is made. See note 127 supra. Such an assignment will give the broker a property interest. 1 Tiffanx, REAL Property $\S 881$ ( $3 \mathrm{~d}$ ed. 1939). But unless the broker has the right to collect the rentals, the assignment will merely give the broker a chose in action. 1. Tifranx, Lanilond \& Tens t $1107-8$ (1914). Assigning the broker the right to unaccrued rentals and contracting to receive from him the excess of rentals over his commissions is dangerous for the landlord, however. $\mathrm{He}$ is now merely the promisee of a contract and is subject to difficultics of enforcement against the broker's assignees.

130. In order to transfer the complete fee interest, or to rentegotiate the lease, the broker's consent would be required. 2 American LAw of Property $\$ \S 6.10,6.11$ (Casner ed. 1952).

131. See 7 Mertens, Law of Federal Incone Taxation $\$ 38.01$ (1943).

132. But when the landlord's interest is held by a group of investors, it may be advantageous to permit the broker to take his commission in the form of a part of the equity interest, especially where he is an investing member of the group. Sec, c.g., Kahn, Profile-Closings and Openings I, The New Yorker, Feb. 13, 1954, p. 38.

133. See note 100 supra. 
The methods by which the broker can presently attempt to impose liability on the transferee are unsatisfactory. If the broker has a separate brokerage contract he can hold the transferee only in the unlikely event that the transferee agrees to assume the liability to pay. ${ }^{134}$ When the broker's contract is written into the lease, recovery is still speculative. ${ }^{135}$ The "vested right" rationale arms the broker effectively but goes too far in preventing efficient use of the leased property. ${ }^{130}$ Giving the broker part ownership also guarantees him a return, but his permanent participation in earnings may constitute excessive compensation. ${ }^{137}$ And property owners may well object to dilution of their ownership interests.

Current law should be altered to afford the broker a remedy against the transferee which is effective but which will leave the leased property as freely marketable as possible. A partial solution would be for courts to hold that a promise to pay brokerage commissions, if incorporated in the lease, is a covenant running with the land. ${ }^{138}$ Squaring such a result with current doctrine, however, would require ingenuity. To run, a covenant must "touch and concern" the land. ${ }^{139}$ The duty to pay the broker could be said to meet that requirement only on the highly questionable theory that the broker's services benefitted the land by producing an efficient use. And a covenant will not run unless performance of the burden is a benefit to the covenantee. ${ }^{140}$ Absent a doctrinal gyration, the covenant would meet this requirement only where the tenant hired the broker but the landlord agreed to pay his commissions, or vice versa. ${ }^{141}$ In any event, the extreme novelty of conferring the stature of property on a simple contract for personal services may foretell the doom of any such proposal.

Doctrinal problems could be solved, of course, if the promise to pay commissions were made to run with the land by legislative mandate. But again the novelty of the idea might kill it. Even if legislation were passed it would help the broker only when he could write his contract into the lease. Leasing parties might still refuse to incorporate the contract into their lease. ${ }^{142} \mathrm{~A}$ covenant running with the land is clearly an encumbrance on the property. The obligation imposed on transferees could be reflected in the price upon sale of interest in the leased premises. But presumably many transferees would

134. See note $10 \mathrm{~S}$ supra.

135. See pages $682-4$ supra.

136. See text at note 128 sispra.

137. See page 686 stpra.

138. Such a decision would require any person holding the promisor's interest in the leased property to pay the broker. See Clakh, Covenants And Otuer Iriterests Whica RUN with the LaNd 2-4 (2d ed. 1947).

139. Id. at $96-100$.

140. For analysis and criticism of this requirement, see id. at 101-111.

141. In that event, the landlord's covenant is to the tenant's benefit, since the landlurd assumes the tenant's obligation to pay the broker. See note 12 supro.

142. Only when it appears in the form of a promise by one of the leasing parties to the other can the agreement be considered a covenant. 
prefer to pay a set sum and take the property free of the brokerage obligation rather than buy the property for less but become liable to pay commissions of unascertained amount. Leasing parties, feeling that the alienability of their interests will be hampered, may avoid the covenant running with the land by keeping the broker's contract out of the lease. Hence the covenant cloctrine could never be a complete cure for the broker's problems.

The broker's claim could be secured if he were given a recordable lien on the leased property. No matter where the promisor goes, the property is available. To be sure, granting the broker a lien would not require the transferee to promise payment of the broker's commissions. But the interest in the realty would be subjected to the lien. In order to avoid continued harassment through enforcement of the lien, the transferee would be forced either to pay the broker himself or to procure substantial assurance that the original promisor would continue to pay. In either case the broker's continted recovery is guaranteed.

Although a broker's lien may be established by agreement, ${ }^{143}$ courts currently refuse to create such liens by judicial process. ${ }^{144}$ They often hold that the broker's action against the original promisor is adequate. ${ }^{146}$ Under similar circumstances statutes granting materialmen's and mechanics' liens have been enacted. ${ }^{146}$ Legislative creation of a broker's lien seems in order. The basic provisions of such a law should include the following. ${ }^{147}$

143. Such an agreement would create an equitable lien. 1 JoNes, LiENs $\$ 27$ (3d cd. 1914). The lien would give the broker an interest in the leased property superior to that of other creditors, but it would not assure enforcement against assignees. The broker could collect from all assignees of the promisor, except bona fide purchasers who took without notice of the lien. 5 Tiffany, Real Property $\S 1559$ (3d ed. 1939). For a discussion of the strict requirements for the creation of such a lien, see JoNEs, op. cit. supra, $\S \S 30-5$.

144. Judicial creation consists of implying an agreement to create a lien in certain situations. Courts refuse to imply such liens from agreements merely fixing the broker's compensation at a percentage of sales or rentals. See Jones, Liens $\S 48$ (3d ed. 1914); Note, 125 A.L.R. 921 (1940). See also Garrett v. Esperanza Mining Co., 93 N.J. El]. 149, 115 Atl. 381 (1921). But courts will imply an equitable lien where the broker is to receive a share of the rents or purchase price. See, e.g., Zerkle v. Hendon, 180 Ala. 209, 60 So. 834 (1913). Such a result is likely in situations closely approximating that in which the Pennsylvania courts utilize the vested rights theory. See note 129 supra. Sec, c.g., Baker v. Cooper, 201 App. Div. 639, 194 N.Y. Supp. 726 (2d Dep't 1922).

145. Phillips v. Catts, 206 Ala. 594, 91 So. 579 (1921) ; Nicol v. Bressler, 159 Fla. 668, 32 So.2d 457 (1947); King v. Wells, 100 Fla. 588, 130 So. 38 (1930).

146. For examples of comprehensive mechanics' lien statutes, granting a lien on real estate to any contractor who has done work to improve that real estate, see ILL. STAT. ANN. c. 82, §§1-39 (Smith-Hurd, 1936) ; PA. Stat. Ans. tit. 49, \$§ 1-268 (Purdon, 1930).

147. A broker's lien law, like a mechanics' lien statute, must deal with a host of ancillary problems, such as appointment of receivers, apportionment of costs, judicial sale of realty interests, and the procedure for bringing suit on the lien. For examples of provisions dealing with these problems, see statutes cited note $146 \mathrm{supra}$. In peripheral areas the problems raised by a broker's lien are not essentially different from the problems covered by mechanics' lien laws. Hence no attempt will be made here to draft a comprehensive set of provisions. Reference may be had to mechanics' lien stattites. 
"Section 1. A broker who performs services in connection with the creation of a lease of real property shall have a lien on all the interests in the leased property held by the party who has promised, by express or implied contract, to pay such broker for such services. Such lien shall not be void, in whole or in part, because the right of the broker to be paid is made contingent by the terms of such contract or because the amount to be paid thereunder is unascertained. ${ }^{148}$ Such lien shall attach on the day upon which the realty is leased. ${ }^{149}$

"Section 2. A broker shall have the right to file record of a lien granted by Section 1 of this Act on the day upon which it attaches or within ten days thereafter. ${ }^{150}$ Such recordation shall constitute constructive notice of such lien and shall render such lien thereafter enforceable against any or all of the interests to which it attaches, whether or not the holder of any or all of the interests against which the lien is enforced is the party who promised to pay the broker. ${ }^{151}$

"Section 3. If payment is not made to a broker having a lien granted by Section 1 of this Act of any amount when such amount is due under the terms of the broker's contract, the broker may bring suit to enforce his lien to the extent of the amount then due, in any court of competent jurisdiction in the county in which the leased property is located. ${ }^{152}$ The bringing of such a suit shall in no way prejudice the right of the broker to bring suit at a later time to the extent of further payments, due at that later time under his contract but not made.

"Section 4. A lien granted by Section 1 of this Act shall not be enforceable to the extent of any payments which became due more than

148. This sentence is designed to protect the broker who holds an "if, as, and when" contract, who has a right to a percentage of variable rentals, or who has the contingent right to additional compensation if the lease is renewed. If such a broker brings his lien before a court to enforce payments due near the beginning of the lease, he should not run the risk of having the court void the lien as to future payments simply because the amount of those payments or the broker's right to them is uncertain at the time of the first suit.

149. A broker who has found a party "ready, willing, and able" to lease may be entitled to compensation even though the premises are never leased. See test at notes 10, 11 supra. The sentence appearing in the text intentionally denies the brolser a lien in that event. If the party hiring the broker is the prospective tenant, he has no interest in the premises until the lease is signed. If the owner of the property has hired the broker to find a tenant, there would be a property interest upon which to affix the lien. But where no lease is signed it seems wise to limit the broker to his remedy against the party who hired him. It is undesirable to place an encumbrance on the property for the benefit of a broker whose efforts did not even succeed in initiating a lease relationship.

150. The object of the ten-day limitation is to preclude the broker from embarrassing the party who promised to pay him by filing his lien just as the promisor is about to sell his interest in the premises. If the broker has not recorded after ten days, the sale can proceed in the assurance that the purchaser will be free of any broker's lien.

151. The "any or all" language in this sentence is designed to prevent the promisor from emasculating the broker's lien by splitting his interests in the realty among several transferees, none of whom would have the same interest in the premises as that which the promisor had. But see text at note 157 infra.

152. This sentence is based on a section of the Illinois mechanies' lien law. Ilw. Srat. ANN. c. \&2, \$ 9 (Smith-Hurd, 1936). 
two years before suit is brought to enforce the lien with respect to such payments. ${ }^{163}$

"Section 5. The holder of any interest to which a lien granted by Section 1 of this Act has attached may notify the person then owning such lien to commence suit thereon. If within 60 days after receiving such notice in writing the owner of such lien fails to bring suit to enforce such lien to the extent of all payments then due, the lien shall be void and unenforceable to the extent of such payments. 154

'Section 6. The term 'broker' as used in this Act shall mean any person licensed as a real estate broker under the laws of this state. ${ }^{155}$

"Section 7. The term 'interests' as used in this Act shall include the contract right to receive rentals, 156 as well as any property right or interest, legal or equitable, which exists upon the creation of a lease. It shall not include the interest held by a sub-lessee."167

This law is designed to allow enforcement of the broker's lien at any time when commission payments are due, despite the fact that original leasing parties have transferred their interests to others. But it is also designed to make the broker's lien as small an encumbrance on the leased realty as is consistent with effective enforcement. Although the lien remains in existence as long as commissions are or may become due, Section 4 prevents the broker

153. See discussion of this section, pages 690-1 infra.

154. This section is patterned after a provision of the Ohio mechanies' lien law. Orno Gen. Code $\S 8319$ (Page, 1937). The Ohio statute provides further that the person who notifies the lienor may record such notice on the docket provided for the recordation of mechanics' liens. Ibid. The purpose of allowing such recordation is to provide evidence concerning the date on which notification was given and to give a later purchaser of the property notice that he is free of mechanics' claims arising before the notification.

For further discussion of this section, see page 691 infra.

155. At one time or another, at least 33 states have licensed real estate brokers. See Semenov, op. cit. supra note 5, at 17.

Defining the persons who may obtain a lien according to licensure may allow a licensed broker who is also an attorney representing one of the leasing parties to obtain a lien to secure payment of his legal fees. Allowing such a result, although not within the central purpose of the statute, seems preferable to complicating the statute by attempting to define the precise services for the payment of which a broker can secure a lien.

156. The right to receive rentals is one of the landlord's most valuable rights. The landlord may split his interests and give one transferee the right to rentals but not the reversion. Similarly the tenant may sub-let the premises and then pass his right to receive rentals and his right of re-entry to different transferees. The provision of the statute should preclude the argument that the broker's lien can not be affixed to the right to receive rentals because that right is not "property." See note 129 supra.

157. It seems unfair to allow the broker to tie up the interests of sub-lessees, who probably had no contact with the broker and did not benefit directly from his services. The possibility that the premises will be leased to a straw man and immediately doled out to a sub-lessee does not make the broker's lien ineffectual. According to this section of the statute, the broker can impose his lien on the tenant's right to receive rents from the sub-lessees, if the tenant has promised to pay the broker. See note 156 supra. 
from using the lien to enforce a stale claim for commissions due years earlier. And the Section assures that a lien which secures periodic payments due under an "if, as, and when" contract will not build up over a period of years into a large burden on the property. Section $\mathbf{5}$ allows the party against whose interest a lien has attached to initiate a judicial determination of the broker's rights; he does not have to wait for the broker to bring suit of his own accord. Thus a party who wishes to contest commission payments can do so, and yet give a potential buyer assurance that all commissions have been paid up to the date of sale-without delaying sale until the broker brings suit of his own accord. Such a lien law seems to strike a fair balance between enforcement for the broker and a minimum of encumbrance on the leased property. 